\title{
Amendments to the International Commercial Code and Its Legal Gaps
}

\author{
Alireza Azadikalkoshki*, Mohsen Hosseinabadi \\ FEBIT International Law Office, Istanbul, Turkey \\ Email: ^f.o.20@febitmail.com
}

How to cite this paper: Azadikalkoshki, A., \& Hosseinabadi, M. (2018). Amendments to the International Commercial Code and Its Legal Gaps. Open Journal of Political Science, 8, 128-138. https://doi.org/10.4236/ojps.2018.82010

Received: November 15, 2017

Accepted: April 10, 2018

Published: April 13, 2018

Copyright $\odot 2018$ by authors and Scientific Research Publishing Inc. This work is licensed under the Creative Commons Attribution International License (CC BY 4.0).

http://creativecommons.org/licenses/by/4.0/ (c) (i) Open Access

\begin{abstract}
For several years, the need to change and amend the Commercial Code is discussed. There is no doubt that the rules must meet the economic and social requirements of their time. The major changes brought about by the advancement of industry and the economy in the commercial relations of individuals make the implementation of these changes and reforms inevitable, and the goals and purposes that are difficult or unenforceable to achieve with the current regulations should be determined. The issue of amendment to the Commercial Code (approved in 1311 with subsequent amendments) has been raised for many years in our country and during this period, trade has been changing rapidly and has never been waiting for an amendment of the law. As a result, we have witnessed negative phenomena in the country's economy, due to the strict separation of Commercial Code and other commercial laws from market realities. Finally, the issue of the need to amend the Commercial Code in August 2002 was approved by the Cabinet of Ministers and the Ministry of Commerce was appointed as the chief responsible for the review of Commercial Code. In this regard, the paper intends to propose a basic approach to amending to the Commercial Code and its legal gaps.
\end{abstract}

\section{Keywords}

International Commercial Code, Amendments to the International Commercial Code, Ministry of Commerce

\section{Introduction}

More than 70 years have passed since the adoption of Iran's Commercial Code, a mother law that is very old, and on the contrary, economics and business have become very progressive. The current Commercial Code, given the conditions for its formulation, namely, industrialization in the conventional sense, in the 
space of the past economy, was a great step that the thinkers of that time took. However, the new economic realities, in particular from the last decade (from 1990 onwards), have made its amendment inevitable. Because the Commercial Code, as a diverse and related set of legal regulations that orders various aspects of business and regulates the legal relationships of economic activists, should, in addition to the principles and theoretical rules, take into account commercial practices, and cover them (Shariatmadari, 2005: pp. 35-29). The first question that should be raised at the start of any action to amend any law is about the need to amend it. Perhaps this question seems to be simple and even inferior to most people. However, due to the lack of attention to the same simple question of amending most of the rules, there are many problems in the adjustment process, and even after approval. In my opinion, in many cases, the current text of the economic laws is of a proper structure and in actions that, for example, have taken place in the draft law of the new guild system and the draft new Customs Code for the most recent changes in the past few years; not only the violations of the current law have not been overcome, but the strengths of these laws have been dimmed. As for the Commercial Code, the author believes that instead of revising the new Commercial Code, a more far-reaching approach to the issue should be adopted. The structure of the Commercial Code adopted in 1311 is based on the needs of the business community of Iran 70 years ago, which is very valuable for its time and even many years after that. But at the moment, the status of the Iranian business community has changed significantly, and therefore, the legal structure needs to be in line with this situation. Therefore, any action to amend the Commercial Code, based on the same structure as before, will be an unwarranted measure (Khazaee, 2008).

\section{The Structure of the Commercial Code}

The current Commercial Code structure is based on 16 sections (Chapter) (Mehr, 2008: p. 2) which seems that the designers of the Commercial Code, in 70 years ago, have tried to provide a mother law for business activities in Iran to cover the major business activities of the community.

\section{The 16 Sections of This Law Are}

1) Businessmen and business transactions

2) Trade offices and business registration office

3) Commercial companies

4) Bill, promissory note, cheque

5) Carrier documents

6) Brokerage

7) Commissioning

8) Commission contract

9) Commercial vice president and other business representatives

10) Guarantee 
11) In bankruptcy

12) In simple bankruptcy and fraudulent bankruptcy

13) In credit restoration

14) Trade name

15) Legal personality

16) Final provisions

As it is seen from the titles of the Sixteen Sections of the Commercial Code, this code deals with diverse commercial issues and unlike most of the current laws of the country, it has not merely considered a particular issue. The main problem in amending this code with the current structure starts from this point, because each of the independent issues addressed by this law, over the past years, has its own specific laws and any changes to the material relating to these matters should be in accordance with the rules in question and since these laws are very scattered and diverse, the application of all these rules in the Commercial Code is a very difficult task, perhaps impractical (Pakdaman, 2006: pp. 71-69). Accordingly, the author's proposal is that, rather than modifying the provisions of Commercial Code and completing them in accordance with current laws, the best way is to integrate the provisions of this law into their own laws. Considering that the examination of individual articles of the Commercial Code is a very heavy task that will take a lot of time, herein, according to the sixteenth sections of the Commercial Code, we pursue the subject of compliance of the provisions of Commercial Code with other commercial laws. The main problem in the current Commercial Code is that there is no specific basis for the preparation of financial statements that is the basis for the decision makers of shareholders, directors and a set of stakeholders and users of information and similarly, there are also no precise criteria in the Inspector's discussion which in the Code has been raised to validate in the form of financial statements and accounting information and to ensure the same respect for shareholders' rights; In order to determine the inspector, the qualification conditions have not been specified, and for the task of the inspector, specific criteria and standards have not been considered (Naderian, 2005: p. 36). With these two great gaps in the current law, we examine briefly the bill to amendment to the Commercial Code and its innovations in a number of ways, following the presentation of the law of the guild system, the Securities Act, the law of corporate affairs, etc.

\section{The Law of the Guild System}

In my opinion, the issues of the following chapters of the Commercial Code are directly related to the activities of the law of the guild system and it is essential that the provisions of these chapters be matched with the guild system And if some parts of these materials had not already seen in law of the guild system, they would have applied to the law of the guild system and otherwise the provisions of these chapters would been exempted from the law of the guild system.

a1) Sixth chapter

a2) Seventh chapter. Commissioning 
a3) Eighth chapter. Transportation contract

a4) Fourteenth chapter. Trade name

a5) First chapter. Businessmen and business transactions (the topics of this chapter are sometimes related to the law of the guild system, although the main focus of this chapter is to distinguish commercial activities from non-commercial activities. It seems that this distinction is currently mainly related to income tax, and it can be raised in the form of Direct Tax Code).

\section{Securities Act}

Some chapters of the Commercial Code deal with financial aspects of business activities, but it is better to integrate the provisions of these chapters into the new Securities Act. In particular, provisions 210 to 219 of the Commercial Code are about cheque, most of which, according Issuing Cheque Act, have been extinct. Therefore, basically the insertion of these obsolete provisions into the Commercial Code is also legally inaccurate. The provisions of these chapters, along with other provisions on other securities, including corporate bonds, which are currently widely traded, can form the core structure of a Securities Act.

\section{The Intended Chapters of the Commercial Code Include}

b1) Fourth chapter-Bill, promissory note, cheque

b2) Fifth chapter-Carrier documents (Pakdaman, 2006: pp. 69-72)

\section{Corporate Affairs Act}

Today, many joint stock companies are a means of tax evasion in order to use special privileges to remove the assets of managers and founders from possible offensive of future creditors. Most of today's companies are family firms that, in addition to having a limited liability by office, can easily divide their wealth of interest, without reflecting in the sealed offices, between stockholders who are family members and they may still leave the imaginary figures in the name of the company's assets and reserves in the offices, which, on the day of the liquidation or bankruptcy of the company, will not pay for the company's creditors. If there are no solid joint stock companies in Iran, small savings will not be made for large industrial and development investments, the transaction will continue on land and immovable property, and it will remain from the stock exchange only, an empty and meaningless word and the separation of management from ownership, as it was intended to convey the legal foundation of a joint stock company, will not materialize. Now, let's see what the purpose of the provisions related to joint stock companies must provide:

1) Supporting investors in the company, i.e. shareholders; this means that there are conditions that the owners of savings who want to invest in and contribute to a company make sure that the founders of the company have accurately provided the forecasts and that the fraud opportunities are not given to the founders or managers of the company. 
2) Supporting a few classes of shareholders who have the privilege of rights and with the confidence and faith in using those rights have invested in the company.

3) Reasonable support from minority shareholders, against the majority of shareholders.

4) Supporting the company's creditors and bondholders and those who deal with the company.

5) Avoiding resorting to ways to escape enforcement of the law by the company's mask (Mehr, 2008: pp. 53-50).

By exposing this material, people invest and buy shares with open eyes and with more confidence. The guarantee of the implementation of these regulations, in addition to the legal and penal liability of managers, founders and experts who have confirmed the content of this announcement, is that the stockholders can cancel their contract or founders and managers who have not disclosed their interests, would be prosecuted to turn the difference into the company (ibid. 54). Given the above, it should be noted that a significant part of the Commercial Code has been devoted to issues related to the activities of commercial companies. The insertion of these items is currently misleading. Because, although according to the bill to amend part of the Commercial Code (approved in 1347), the provisions related to the joint-stock companies, consisted of 200 items, have completely changed, yet provisions related to joint stock companies (approved in 1311), have been preserved in the collection of the Commercial Code and this often leads to a different understanding of the rules relating to joint stock companies and even other commercial companies. In my opinion, the business community in our country is in dire need of setting up an independent law on corporate affairs. In most developed countries, there is also such a law. Among others, it is possible to refer to the Companies Act, adopted in 1985, in England. The following described chapters of the Commercial Code are transferable to the new corporate law.

c1) Second chapter-Commercial offices and commercial register

c2) Fifteenth chapter-Legal personality

c) Ninth chapter-Commercial vice president and other business representatives

In relation to the shares of the companies, it should be added that the introduction of shares without a formal value, in an era in which people believe that the purpose of joint stock companies should not only be to protect the interests of shareholders, but also to preserve the public interest and the interests of the company's employees, it is a pity that we do not urgently resolve the major obstacles to the growth of joint stock companies in Iran and do not provide regulations that are in line with today's needs (Mehr, 2008: p. 67).

\section{Bankruptcy Law}

Bankruptcy is one of the special issues raised in the Commercial Code, which is 
specifically addressed in the following two articles, from Provisions 412 to 575:

d1) Eleventh chapter-In bankruptcy

d2) Twelfth chapter-In simple bankruptcy and fraudulent bankruptcy

d3) Thirteen chapter-In Credit restoration

In terms of these provisions, there are a few points: First, some of the provisions of this section of the Commercial Code, seems implicitly or explicitly have been repealed, first, some of the provisions in this section of the Commercial Code seem to be implicitly or explicitly repealed, or at least, on the basis of which the judgment is not issued by the court. Including, Provision 562 provides:

"Credits cannot claim damages for more than five years because of a delay in paying their credit" and anyway, claiming accessories each year, should not exceed $7 \%$ of their credit. Secondly, the main executor of this section of the Commercial Code is the Judiciary. In addition, provisions related to bankruptcy due to fault or fraud also have a criminal aspect.

Thirdly, in relation to bankruptcy, other laws are currently effective and enforceable, including:

1) Law on Bankruptcy Insolvency Administration (approved in 1318).

2) The Law on the Use of Income of A \& B Funds of the General Directorate for Bankruptcy Insolvency (approved in 1344).

3) The provisions of Non-Litigious Matters Act (approved in 1319).

4) The provisions of the Code of Civil Procedure (approved in 2001) (Pakdaman, 2006: pp. 75-67).

So my suggestion is that these three detailed sections of the Commercial Code, as well as supplementary provisions of these rules should be merged as an independent law of "bankruptcy".

\section{Other Cases}

Except for the provisions of the Commercial Code that their relationship with other rules were described above, the other two chapters of the Commercial Code remain that are as follows:

e1) Tenth chapter-Guarantee

d2) Sixteenth chapter-Final provisions

In the case of provisions for guarantees, Civil Code has more accurate and more complete provisions that in order to avoid conflict of laws and controversy in the interpretation of the relevant provisions, it is better to integrate the guarantee provisions of the Commercial Code into Civil Code. Also, the final provisions of the Commercial Code have had dispersed provisions in different chapters of this Code, which according to the case, may be merged into these chapter or repealed. In spite of the points outlined above, we should consider other modifications that in the Bill on Amendments to the Commercial Code, under the provisions of Articles 4 to 11 the second chapter, entitled "Rights and Obligations of the Businessman" and "The Register of Commerce", a new definition 
has replaced Articles 7 to 13 of the current Code that we will describe it below.

A. in Article 4, the registers where the businessman is required to maintain them is defined as follows:

Article 4: Any trader, except for small businessmen, is required to have the following (paper or electronic) registers or any other register that the government may replace under the regulations.

1) Daily register

2) Ledger

3) Inventory

4) Correspondence Register

B. in Article 9, the legality conditions of commercial registers are as follows:

Article 9-If the registers mentioned in Article 4 of this law (with the exception of the Correspondence Register) are arranged and stored on paper, they must be signed by the representative of the registration department and the number of pages and details of the owner of the register should be written on its first and last pages. These offices should have an orderly score and all transactions and financial operations should be written in special pages in the order of history. Any shaving, carving, leaving space, writing down the lines, and so on, is prohibited in these registers.

The main difference between the aforementioned articles in the Amendment to Commercial Code with the current Code is the identification of a new type of legal office called electronic registers, which is applicable to individuals, with the exception of small businessmen, and does not need to be sealed, stamped and signed by the officer of company registration and industrial property department. The form and method of using the electronic above-mentioned register, which is a new term and a definite definition of it should be presented, is subject to the formulation of the relevant regulations, as described in Note 4, Article 9, as follows. It seems that, if accounting standards are met, part of the controls under the Commercial Code and the Direct Tax Code will be applied appropriately. A note that, in line with the above, should be added is that: The bylaws related to the registers and how to arrange and maintain them are done by the Ministries of Commerce and Economic Affairs and Finance, within 6 months from the date of the adoption of this law and in accordance with the law of e-commerce and the development of the country's economic situation and the volume of business activities and the prevalence of modern computer accounting systems. This bylaw, after approval by the Council of Ministers, will enter into force (Keshani, 2005: p. 56).

The above note has several positive and negative fundamental points:

1) The reference to e-commerce, which has caused commercial operations to be done in the virtual environment and recorded in electronic offices, and their financial implications appear in the financial statements of the merchant. Due to the fact that in electronic systems, information is entered as zero and one code, and when required, is presented in accordance with the format desired by the user, in the form of the daily register, ledger and certain cards, the parts of the 
balance of the operation of accounts and special reports, Therefore, the evolution of accounting records and account maintenance is expected, which has been felt for years.

2) The reference to the impact of the development and evolution of the country's future economic state and possible changes that the above agents can create in accounts registration and maintenance systems in harmony with the advancement of electronic systems in the future. This clause makes it possible, in the event of the realization of a program for the creation of an e-government, without changing the Commercial Code, to meet the needs of the time in line with the new possibilities.

3) Given the volume of business activity and the change of systems in line with the extent of business activities, as one of the factors determining the methods of registering operations at legal offices, at present, by forming large joint stock companies, in fact, the possibility of implementing part of the Articles 7 and 8 of the Commercial Code and the provisions of Bylaw 2 Article 95 of the Direct Tax Code is subject to fundamental constraints. Past experience suggests that laws that are not enforceable under normal circumstances and procedures are likely to reduce the incentives for the legalism and increase the law aversion and law enforcers also ignore the non-implementation of it; Such as Article 9 of the Commercial Code concerning the Property Office.

4) In spite of the attention of the Bill on Amendments to the Commercial Code to the laws and regulations that are associated with it and their names have been inserted in the introduction of the bill, as the laws and regulations that have been considered in its drafting, accounting standards, which are required by Audit Organization Establishment Act as of 1/1/1381, are not mentioned. While accounting standards play a key role in how to register accounts and prepare financial statements, and legal offices of any form, whether paper or electronic, without a standard, will have not proper and uniform meaning. It seems that, if accounting standards are met, part of the controls required by the Commercial Code and the Direct Tax Code will be applied In the text of Note 2 of the bylaw of the Article 95 of the Direct Tax Code, reference is made to observing the accepted principles and standards of accounting, as suggested previously in the proposed amendment. However, as mentioned above, the direct tax law has shown attention to the legal offices and the accounting system, from only an instrumental point of view, for calculating taxable income. Therefore, it approves those standards, which do not increase the cost and thus do not reduce the taxable profit. It seems that, given the possibilities offered by the information systems, and are changing in terms of quality and speed, on the one hand, and the increase in the volume of operations of public joint stock corporations and the prediction of future developments arising from global trade and e-commerce, on the other hand, the amendment to the bylaw of Note 2, Article 95 of the Direct Tax Code in relation to the provisions of the legal offices, which have been examined here, not only are not accountable to the current needs of enterprises, but also it does not have necessary coordination with the Bill on Amendment to 
the Commercial Code, foundations and principles (Keshani, 2005: pp. 59-55). It is hoped that during the drafting of Article 9 of the Bill on Amendment to the Commercial Code, the Ministry of Economic Affairs will show more attention the accounting standards as the necessary legal requirements, in matters relating to the legal offices and the procedure for the registration and maintenance of accounts, and apply the controls necessary for the actual recording of the operations of each economic unit through the exchange of information and the emphasis on comparing information within the firm with the information obtained from the other party, and pay attention to the principle that the cost of any firm is the income of the other firm or firms. In the amending bylaw of Note 2 of Article 95, other provisions also have predicted that it seems that are not consistent with current economic conditions and electronic developments; however, due to the provisions of the Bill on Amendment to the Commercial Code, which, if approved, would exclude these cases, it has been denied details. The Bill on Amendments to the Commercial Code and its innovations After mentioning the above mentioned cases, it is necessary to pay attention to the innovations of the bill to amend the Commercial Code; In the Bill on Amendment to the Commercial Code, the commercial space has been defined more transparently, while defining the used definitions and concepts, the cases in the current law that have gaps or the law has passed them with silence, have expressed in the Bill explicitly and Clearly.

1) One of the new economic phenomena is the issue of parent companies and affiliated companies and subsidiaries and, in general, affiliations that different companies can have in terms of ownership or management. The bill tries to provide clear and comprehensive definitions in this area.

2) One of the problems with the current law is the multiplicity of inspectors. If there are plenty of comments from inspectors, there are problems for users of financial statements that have not been raised in the new bill of the multiplicity of inspector.

3) In the Bill on Amendment to the Commercial Code, special attention has been paid to financial discipline in order to prevent rent-seeking and create a healthy environment for business competition in many cases.

4) The focus of accounting and auditing standards; It may be said that the punch line of the amendment to Commercial Code in the department of financial and accounting regulations is the definition of financial statements in accordance with the accounting standards and making the board responsible to prepare the company's financial statements in accordance with accounting standards.

5) Improving the role of the auditor and legal inspector; the scope of the inspector's powers was limited to the general rule, and in many cases, the managers' actions did not require the comment of the inspector. In the amending bill, the scope of the inspector's powers has been expanded to a considerable degree.

6) Increased enforcement guarantee of the law; the current law does not, in many cases, provide for a serious enforcement guarantee to enforce the provi- 
sions of the law and, therefore, it is possible not complying with the law or to take unlawful measures. The amending bill provides for sufficient and comprehensive enforcement guarantee for the compliance with the law (Naderian, 2005: pp. 40-35).

\section{Conclusion}

The Commercial Code, in the present form and content, does not correspond not only to the current conditions of the international business community, but also with the current conditions of the Iranian business community, because it does not cover many topics that are directly related to trade, for example, foreign trade, which is currently covered by the law of export and import regulations. In addition, e-commerce is also one of the key issues in today's world trade, which has not been clarified in the Commercial Code. Although the draft of e-commerce law has been prepared by one of organizations, there are several disadvantages in this draft, which the author has already referred to in a series of articles. Also, the various sections of the Commercial Code now have their own rules and, therefore, in many of these cases, these sectors have essentially been repealed and their presence in the context of Commercial Code only causes ambiguity and doubt about the governing law. Therefore, the Commercial Code with this current structure cannot basically be a basis for amendment and completion and in my opinion, instead of having a flawed Commercial Code, it is better that the specific rules of each subject be supplemented by the provisions of this law and all other waste and repealed provisions be removed from the scope of the country's laws. In this regard, it is suggested that, while transferring the relevant material in the Commercial Code into the law of the guild system and civil code, the following independent laws shall also be developed using the provisions of this Code and other relevant Codes.

a) Corporate Law

b) Securities Act

c) Bankruptcy Law

In the end, it should be added that the amending bill of Commercial Code was the result of three years of continuous research-advisory effort, which was developed using the ideas of professors, experts, industry owners and experts of executive agencies and specialists in a dynamic and interactive process, and it includes major innovations that its approval, can flourish the commercial space of the country and is very effective in developing business activities.

\section{References}

Keshani, F. (2005). Bureau of the Law on Amendments to Note 2, Article 95, and the Bill on Amendments to the Commercial Code. Auditor's Quarterly, No. 29.

Khazaee, H. (2008). One of the Legal Gaps of the Bill on Amendments to the Commercial Code, Law Quarterly. The Journal of Law and Political Science, 38.

Mehr, F. (2008). The Change and Amendment to Commercial Code. Tehran: Institute for Humanities. 
Naderian, H. (2005). A Review of the Bill on Amendments to the Commercial Code and its Innovations. Auditor's Quarterly, 29.

Pakdaman, R. (2006). An Essential Approach to Amendment to Commercial Code. Trading Studies Quarterly, 181-182.

Shariatmadari, M. (2005). Commercial Code Amendment of the Necessities of Economic Development. Auditor Quarterly, 29. 